This is the pre-print manuscript version of this article which has been published as

'Chinese litigants in late colonial court-rooms', Journal of Chinese Overseas 9, 2,

2013, pp. 193-211: DOI: 10.1163/17932548-12341259

\title{
Law as Politics: Chinese Litigants in Australian Colonial Courts
}

\author{
Mark Finnane
}

\begin{abstract}
The recent historiography of Chinese in Australia has emphasised their vigorous formation of a local identity and community even in the face of recurrent and expanding threats of exclusion from colonial life. In their ready embrace of legal remedies to redress what they saw as discrimination or other harms, the Chinese were exemplar colonial settlers who looked to the law to protect them. In colonial appeal courts, Chinese litigants challenged migration controls, contested convictions under opium restriction and gambling laws, sought equitable outcomes in property inheritance and challenged exclusionary regulation under the Factory Acts. In contrast to another kind of history of the Chinese in Australian law, as defendants in criminal prosecution, this article draws attention to the Chinese engagement in legal remedies as an assertion of their entitlement to recognition and fair play.
\end{abstract}

\section{Keywords}

Chinese immigrants, Australia, law courts, litigation

* Mark Finnane is Australian Research Council (ARC) Australian Professorial Fellow and a Professor of History at Griffith University, where he is a Chief Investigator in the ARC Centre of Excellence in Policing and Security (CEPS). He has published widely on the history of criminal justice, policing, punishment, and criminal law in both Australia and Ireland. His most recent book, with Heather Douglas (University of Queensland), is Indigenous Crime and Settler Law: White Sovereignty after Empire, published in 2012 by Palgrave Macmillan. 


\section{Introduction}

The recent historiography of the Chinese in Australia has emphasised their vigorous formation of a local identity and community even in the face of threats of exclusion from colonial life (Jones 2004; Fitzgerald 2007; Khoo \& Noonan 2011; Ngai 2011). A striking example of this resilience can be located in the records of colonial courts hearing legal cases involving Chinese litigants, not only as defendants but as plaintiffs and appellants. In their ready embrace of legal remedies to redress what they saw as discrimination or other harms, the Chinese litigants were exemplar colonial settlers who looked to the law to protect them. In this article, I address this history through examining the fortune as well as the fate of Chinese litigants in Australian colonial court-rooms, examining cases that escalated to appeal courts.

A United States study of similar phenomena in American law in the late nineteenth century took as its theme the 'Chinese contribution to American law' (McClain \& McClain 1991). A further American study accented this theme, tracing the influence of determined Chinese litigation on subsequent congressional policy that shaped modern American immigration law and administration (Salyer 1995). In that case, as in Australian colonies and in Canada (McLaren 1991), a great deal of the foundation of modern immigration law was formulated in response to Chinese-initiated litigation. While some of the leading Australian cases are well known, they have generally been subordinated in the history of Australian immigration law to the study of the racialising discourses of the time to the politics of White Australia (Lake \& Reynolds 2008; Willard 1967; Yarwood 1964). This litigious activity deserves greater scrutiny for illustrating the strength of the Chinese community networks that supported and initiated such litigation in the period before federation; for its 'contribution' to the history of Australian law; and for its illumination of the political dimension of litigation, of a politics conducted through the law courts. Importantly, the range of cases reaches beyond 
the immigration field, with Chinese litigants challenging opium restriction laws, seeking equitable outcomes in property inheritance and contesting exclusionary regulation under the Factory Acts. In contrast then to another kind of history of the Chinese in Australian law, as defendants in criminal prosecution, this article draws attention to the Chinese engagement in legal remedies as an assertion of their entitlement to recognition and fair play in the countries of their diaspora.

\section{Litigants and Defendants}

As immigrants (short and long-term) and as settlers, Chinese were participants in the shaping of the colonial societies of Australasia. Their sense of themselves as settlers was forged in the angry politics of exclusion. Against the repeated attempts of colonial states to restrict their passage into the colonies, the Chinese worked in conventional political styles as well as informal 'work around' modes to secure their rights of entry and residence. The conventional political styles were most obvious in the two largest Australasian colonies, Victoria and New South Wales (NSW), with leading and successful Chinese entrepreneurs lobbying political leaders directly on behalf of their individual and collective interests. In assessing the importance of litigation as politics, it will also be helpful to locate this phenomenon against the broader experience of Chinese interaction with the law. Australian scholarly treatments of this interaction have highlighted the vulnerability of Chinese immigrant and settlers as defendants in criminal cases, or victims of police harassment and media demonisation in gambling prosecutions (Jones 2004; Cronin 1982; Holst 2004; Macgregor 1995; May 1984; McCoy 1980; Ryan 1995a). There is hard evidence of the severity of colonial attitudes towards Chinese (and other Asian) offenders when serious crimes were committed - in the greater likelihood of the death penalty being carried into effect when such punishment followed conviction for a capital crime (Finnane and Richards 2010). 
Yet this sorry story of violence and discrimination in equal measure cannot be allowed to stand alone as the history of Chinese interaction with colonial law. On the one hand, there were some contexts where Chinese were only rarely the subject of police charges for minor offences like drunkenness for example in rural Victoria in the later nineteenth century (Holst 2004). And even in the context of the fractious racial politics of the 1891 NSW Royal Commission 'into Chinese gambling and immorality', the Commissioners were inclined to emphasise the generally law-abiding reputation of Chinese residents and settlers (NSW Parliament 1891). On the other hand, as this article explores, Chinese immigrants and settlers were also assertive in going to law to prosecute their own interests and defend their rights. Their readiness to appeal the judgment of Australian courts suggests a resolute population determined to resort to law when necessary to assert or defend their rights or interests. I draw this conclusion from a review of published appeal judgments in late colonial courts and in the early Federation period. In the published lists that were generally marked by the absence of litigants who were not of the majority Anglo-Celtic populations, Chinese litigants may not have been common, but their presence was frequent enough to be noteworthy and in some cases of considerable consequence for Australian law and politics. This is most clearly the case in that demon of Australian historiography, the White Australia Policy, where Chinese litigation, as I will argue, was an historical factor of some consequence. However, Chinese litigation was by no means restricted to immigration cases. The variety of cases in which Chinese litigants appealed to higher courts is testimony to their diverse engagement in colonial society. The outcomes of those cases also suggest the capacity and limits of the British legal system to recognise their status and rights.

Some light is shed on the context for these actions in the limited studies that have noticed the appearance of Chinese in civil as well as criminal litigation. Against a presumption that Chinese avoided litigation, studies by Jan Ryan in Perth and Cathie May in 
Cairns observed significant numbers of Chinese litigants in later nineteenth century courts (May 1984; Ryan 1995a). They appeared as both plaintiffs and respondents. Sometimes the cases were within the Chinese community, though possibly more so in Cairns than Perth. In Cairns, May reviewed both civil and criminal litigation, finding police highly prejudiced in their disposition compared to a more balanced approach taken by magistrates and judges. Similarly, in analysing both civil and criminal cases in Perth between 1880 and 1900, Ryan found a largely dispiriting story of Chinese litigants facing prejudiced juries and unsympathetic judges. The volume of litigation however, also implied the confidence of litigants in the possibility of obtaining positive outcomes in their favour. Indeed Ryan suggested that the more fragmented population of the Chinese in Perth, lacking familial and fraternal protection available in other parts of the diaspora, proved very ready to seek protection or satisfaction in the courts (Ryan 1995a: 90-7, 1995b: 343,351). In Castlemaine and its environs in the Victorian goldfields, Holst uncovered a steady stream of civil litigation, with success in debt recovery and even assault cases. In one of those towns, Fryerstown, Holst also discovered a disturbing picture of magisterial prejudice associated with the tenure of one particular magistrate; after his departure, a more equal justice returned to the local court (Holst 2004: 127). A review of appeal court cases in other jurisdictions tends to confirm that conclusion, as we will see.

It will be helpful to indicate briefly the structure of colonial justice systems. By the later nineteenth century each Australian colony had its own Supreme Court, of at least two and in some places more judges (Bennett 2003; Bolton \& Byrne 2005; Castles 1982; Kercher 1995; McPherson 1989). The Supreme Courts had original jurisdiction in some matters including criminal trial of capital offences and more substantial civil matters, as well as common law procedures such as the hearing of prerogative writs like habeas corpus (requiring judgment over whether a person was lawfully detained in custody). These courts 
also heard appeals from judgments of lower courts, on legal and procedural grounds. Judges of the Supreme Court were appointed on Crown commission with their tenure conditional only on good behaviour. Although their removal from office was not unknown, this was a rare occurrence, and assertive judges insisted on their independence of government (McLaren 2011). Yet to a fair degree they were also part of government, and in colonial times assisted in the preparation of legislation and even sat as members of Executive Council in the early days of some colonies (Bennett 2006). In the trial and sentencing of capital offences (mainly homicide) the Supreme Court judges retained the role of advising executive government on the fate of persons condemned to death; and many so sentenced were saved from the gallows by a judicial recommendation for mercy (Strange 1996; Woods 2002). After the Federation of the colonies formed the Commonwealth of Australia in 1901, the High Court of Australia was established as a court of appeal from the State (formerly colonial) courts - in the period covered in this article, the High Court sometimes heard appeal cases directly from a lower police court. Although the Privy Council of the United Kingdom remained the ultimate court of appeal for Australian litigants until 1975, only one case considered in the period here went to the Privy Council.

Drawing on the published law reports and digests of the Australian courts for the period from the gold rushes to the First World War, I have identified 67 cases (see Appendix) between 1864 and 1912 in which Chinese litigants were party to the contest. In a few of these cases (usually contract cases) both plaintiff and respondent were Chinese. Most appeal cases were non-criminal, involving administrative or executive decision-making, increasingly around immigration law, but appeals were also found in areas including private law, contract, and estate administration. A significant minority was made up of gambling and opium possession prosecutions in which Chinese litigants proved vigorous challengers to police actions. It is important to note that the scope of the discussion in this article is limited 
generally to 'appeal courts' - for the most part we do not address the degree to which Chinese defendants (generally through their lawyers) successfully deployed legal defences against police charges in gambling or opium cases or against the discretionary decisions of customs or immigration officers. In sum, however, the appeals court cases highlighted questions of community and individual identity and power in respect of Chinese immigrants, residents and settlers in the Australian colonies.

\section{The Cause of Action}

The range of matters on which Chinese litigants appealed reflected almost entirely the distinctive position of the Chinese in Australia during the late colonial and early Federation years. It is noteworthy then that the first NSW appeal matter published in the law reports was the outcome of a gold-fields dispute. The gold fields in both Victoria and NSW were sites of considerable conflict between Chinese and other miners (Curthoys 2001; Markus 1979). By 1862, not only were statutes in place to control the influx of Chinese seeking their fortune on the gold fields, there were also restrictions on the freedom of those Chinese who did make it past the ports to mine where they wished. In 1864, Ah Tchin and a number of other Chinese miners were convicted at Burrangong in NSW of mining on a gold field that was prohibited to them. Their conviction was obtained even though they possessed a license (the 'Miner's Right') to mine gold, obtained before the restrictive legislation was enacted. Employing expensive senior counsel (Sir William Manning, a leading lawyer and politician) in their cause, the miners appealed their conviction in the NSW Supreme Court. The appeal was dismissed by two of the three judges, and the convictions were sustained. Both judgments delivered were highly critical of the wording of the statute under which the miners were convicted, though Chief Justice Stephen took it on himself to interpret the intention of the legislature to punish such offences as had been committed by the Chinese. In dissent, Justice 
Wise objected to the conviction of aliens who possessed miners' rights under legislation so unclear in its provisions. In doing so he questioned both the legality of a statute that distinguished aliens from others, as well as the 'injustice' of depriving such miners of the vested right that inhered in their possession of a Miner's Right (Ex parte Ah Tchin and others, 1864 New South Wales Supreme Court (NSWSC) 226; see also Sydney Morning Herald (SMH), 26 Sep 1864: 2).

Discriminatory provisions in statute law or policy were the subject of other legal challenges, most notably in relation to the administration of migration policy, a matter we will discuss later. Outside these kinds of cases, the more common factor distinguishing Chinese litigation from non-Chinese might be found in the demand on the courts to consider the particular status or customs of Chinese people in Australia. Approaching the subject in this way, we might say that the challenge was one of 'recognition' - could the legal boundaries of the common or statute law be applied to the ways of life, belief and action of Chinese in their colonial setting? In the Australian colonies, the higher courts constituted a possible forum for recognition of Chinese custom that was in tension with the commonly hostile disposition of colonial policy and opinion. Two examples suggest the possibilities.

Chinese gambling was as much the target of colonial police as of twenty-first century gambling entrepreneurs seeking new markets. Chinese defendants in gambling prosecutions proved to be energetic opponents. Gambling shops were common and well known in all cities - their existence was the subject of the 600 pages of evidence gathered by the 1891 NSW Royal Commission into Chinese Gambling and Immorality. That commission noted something that is of broader interest to our subject. Commenting on secret societies, which they characterised as "tongs", the commissioners concluded from their evidence that most were benign, operating as mutual benefit organisations with functions including support for their members and the transport of bones of the deceased back to China (Cai 2004; Fitzgerald 
2007: 57-97; Yong 1977: 157-168, 189-195). The one society (the Loon Ye Tong) that they considered illegal 'appears to have consisted principally of gamblers, and to have devoted its funds very largely to defraying the legal expenses occurred in their defence when prosecuted, and the penalties in the event of conviction' (NSW Parliament 1891: 27). Like other such societies for example in Castlemaine and in Melbourne, the members of this association were collaborating to support their countrymen in difficulty, such as enabling legal defence in case of prosecutions or other legal troubles (Holst 2004; Welch 2003).

Perhaps it was such support that lay behind the response of Li Chi and his lawyers in 1881 to a Sydney police charge of keeping a common gaming house. The house in inner-city Darlinghurst was occupied exclusively for the playing of the Chinese lottery "pak-ah-pu". Li Chi and three others were charged and convicted at Quarter Sessions, but appealed their convictions. In the Supreme Court two judges, including the Chief Justice, declined to accept the prosecution case that "pak-ah-pu" was a 'game'. The case turned on a detailed account of the conduct of "pak-ah-pu" which seemed to Justice Windeyer to be more of a lottery than a game. The Chief Justice observed that in such a case the actions might have come within statute law relating to lotteries, but that was not the information made out by police who were relying on the common law charge alone ( $\mathrm{R} v$ Li Chi and others, 1881 NSWLR 189). The convictions were quashed and police were left to explore other ways of suppressing such establishments - later this was facilitated by the inclusion of pak-ah-pu (as well as the gambling game of fan-tan) in police offences statutes (O'Hara, 1988: 114-7). Such histories of legal battles followed by policy or statutory change suggest the degree to which Chinese resistance was perversely shaping the structure of regulation, a phenomenon I will argue was more starkly demonstrated in immigration law.

A quite different story of recognition (and its limits) was evident in the private law domain of marriage law and estate administration. In 1911, a Chinese-born widow with five 
young children was granted estate of her deceased husband, Fon Hock, a Chinese-born resident of Tasmania since about 1886, and whose property included mining and water leases. Fon Hock had died intestate and so his property might have been forfeited to the Crown or even to Fon Hock's mother and brothers who were also represented in the action; but the Curator (responsible for overseeing the disposal of estates) asked the Supreme Court to adjudicate. Both widow and mother were represented by legal counsel. The court accepted that marriage according to Chinese rites had taken place, in both China and Tasmania - and set aside for want of evidence, a suggestion by counsel for Fon Hock's mother that there had been a prior marriage to another woman in China. From the Chinese Consul-General in Australia, the court received advice that concubinage was common in China. When the mother's counsel attempted to dismiss the legitimacy of Chinese marriage rites (China 'being a heathen and polygamous country'), one judge interposed: "If this marriage is no marriage must I not also hold that his parents' marriage was no marriage, and that there is no one entitled to succeed?" In spite of the Curator's counsel complicating matters further by questioning the court's capacity to recognise Chinese law, the Curator had already determined that there was no objection to the widow and children benefiting from the estate. This eased the court's path - and in delivering judgment the Chief Justice added a declaration to the effect that there had indeed been a marriage. The alternative conclusion that there had been no marriage capable of recognition in Tasmania was an unpalatable one, given its consequences - and so the Chief Justice declared his pleasure at the outcome, for the 'woman has been living with the deceased as his wife, and ... she and her children should have the estate' (Re Fon Hock 1911 TSC 25). In such a case, the Supreme Court exercised its discretion by throwing a veil over the hostile evidence, concerned to avoid throwing a family into penury and potential dependence on the state or charity. The small scale of some Australian jurisdictions may have lent weight to makeshift decisions where the interests of 
women or children were at issue - thus in 1908 a judge of the Queensland Supreme Court ordered the investment of a sum of money from a deceased estate to be made available to support the widow and infant child, Ah Lin, who had both returned to China (In re Ah Lin, 1905 Queensland Supreme Court Weekly Notes (QSC WN), 59; In re Ah Lin, 1908 QSC WN, 26).

The long record of discriminatory legislation directed at Chinese settlers included not only licence and residence regulation but controls over employment. In industrial legislation of the later nineteenth century, the colonies sought to limit the potential of Chinese businesses to compete with non-Chinese (Yong 1977; Markus 1979). When Western Australia enacted a new Factories Act in 1904, it not only required prohibitive registration costs for 'factories' owned by Chinese, but debarred Chinese from employment in a factory unless they had been employed there before November 1903 (Factories Act 1904 sec. 46). In 1905, four Chinese employers running laundries in Perth appealed their convictions under this Act for employing Chinese labourers in their factories beyond the statutory closing time of $5 \mathrm{pm}$. Their counsel challenged the constitutional validity of the Act but the two judges of the Full Court on that day did not find it necessary to go beyond dismissing the charges on the basis that the information before the court had not described the employees as persons of the Chinese race, as required by the statute. It was evident however that these judges found little to admire in what Justice Parker called 'this most extraordinary piece of legislation', which he was surprised had not occasioned objection from the (British) imperial government (R v Lee Shew and 3 others, 1905 WA Supreme Court: West Australian, 30 Sep 1905: 8). The convictions were quashed.

Constitutional issues were raised a year later in another Western Australian appeal against convictions under this same Factories Act. They ranged from claims that the powers of the Factories Act were ultra vires the Western Australian Constitution, to invocations of 
the ancient Magna Carta and the repugnancy constraints applying to the validation of colonial laws. By this time, however, the same judge who had found the legislation 'extraordinary' was now the Chief Justice; he proved less persuaded of any constitutional arguments offered by counsel for the two Chinese appellants, Ah Ying and Ah Chung. In dismissing the appeal, the judges of the Supreme Court also affirmed the right of a colonial legislature to enact its own laws; when counsel raised the potential incompatibility of the statutory discriminations of the Factories Act with the treaty between the United Kingdom and China, the judges simply insisted that they could take no notice of such a treaty (Ah Ying and Ah Chung v Vincent 1906 WA Supreme Court: West Australian, 31 Jul 1906: 4). Another casualty of the Factories Acts, Lee Fay, appealed to the High Court of Australia in 1909 but again without success: in that case Lee Fay attempted to invoke the constitutionally protected freedom of movement and action between states of the Commonwealth (Lee Fay v Vincent 1908 HCA 70). During the earlier stages of Lee Fay's litigation, the fact that he was a naturalised British subject did not prevent the application of the Factories Act to him as one of Chinese origin (see Lee Fay v Vincent, affidavits, Cons. 3677/613, WA State Record Office). In refuting any attempt to argue for the rights of naturalised British subjects of Chinese origin (as the appellants' counsel had been implying), the Western Australian judiciary was falling into line with a settled Australian opinion. That line of thinking had been tried and tested with mixed outcomes in the 1880 s immigration cases, which we now consider.

\section{Aliens, British Subjects and Colonial Politics}

The history of the White Australia Policy is not only a history of the politics of racialist ideologies and exclusion. It is also a history of law and government. In that history, Chinese litigants played a creative role in resisting, attempting to work around, or work within the constraints of statute and administration. In a thorough inquiry into the administration of the 
White Australia Policy in the first four decades of the twentieth century, Paul Jones demonstrated that the policy may be better thought of as a mechanism for the regulation of Chinese movement in and out of Australia rather than as simply a policy of exclusion. That is because Australian, as well as Chinese interests, diplomatic and commercial and personal, were best served by a policy that facilitated the mobility of people, goods and money (Jones 1998. and see also more generally McKeown, 2008). This is not to deny the impact of the policy in shaping Australia population composition in the first half of the twentieth century, during which the Chinese-born resident population of Chinese origin declined steadily. But stressing only the exclusionary object of the White Australia Policy runs the risk of obscuring the continuous history of Chinese engagement with Australia during these decades, a history as Jones has commented, of Chinese as 'settlers, and in many ways, agents of their own progress' (Jones 2004: 220).

The productive use of legal remedies to test the limits of the White Australia Policy had a pre-Federation history that has been little appreciated from the point of view of its role in Australia politics in the late colonial period. I want to draw attention in this section to the significance of the legal challenges to colonial immigration restriction in terms of both their demonstration of Chinese assertion of rights and interests, and of their impact on colonial law and politics evident in the progressive and controversial hardening of immigration law and administration.

The centenary of settlement in 1888 witnessed a crisis in colonial politics when boats were prevented from disembarking their Chinese passengers, first in Melbourne and then Sydney, in spite of the passengers either carrying the required naturalisation papers or paying the requisite poll-tax in accordance with the law. The decision of the colonial governments of Victoria and New South Wales to direct their customs officials to prevent the landing was a response to growing agitation around the threat of Chinese migration, particularly by an 
increasingly influential and well-organised labour movement in both capital cities (Curthoys 2003; Markus 1979). Resisting the determination of both governments to stem the flow of Chinese immigrants, some suspected of carrying fraudulent papers, a number of Chinese men launched legal actions in the Supreme Courts of each colony. In a number of cases the actions were successful, prompting anxious, even hysterical, political consideration of the need to harden colonial borders. The significance of the cases may be briefly described, as much for what they tell us about the modes of British law and politics in the colonies as about Chinese assertion of their common law rights as subjects in a British colony.

The best known case is that of Chung Teong Toy, a passenger on the vessel Afghan. Toy was a cabinetmaker who had been engaged on contract as a foreman by a relative in Melbourne (Argus 18 Oct 1888: 13). When he arrived in Melbourne in April 1888, he was prevented from leaving the ship, in spite of the captain having offered to pay the tax of ten pounds required by law for Chinese passengers disembarking. The officer preventing Toy from landing was the Collector of Customs, A W Musgrove, who had been directed by the Minister (the Commissioner of Customs) to refuse landing rights to any Chinese other than those who were British subjects. After returning to Hong Kong, Toy sued the Collector of Customs for 1000 pounds in damages. Musgrove's defence was that he was acting as directed by a Minister of the Crown, whose reason was the apprehension of government that a large influx of Chinese into Victoria 'would be a danger and menace to the said colony and to the public peace thereof, and to Her Majesty's subjects residing therein'(Toy v Musgrove 1888 $V L R$ 351-2). Toy's challenge was not easily dismissed. The constitutional issues raised by his counsel Sir John Madden, a later Chief Justice of Victoria, escalated the case from a hearing by a single judge to a case before the Full Court of six judges. There the court divided, with the majority supporting Toy's claim that the Minister's direction was illegal. The constitutional issues remained of the first importance because the Chief Justice, George 
Higinbotham, a former attorney-general and leading liberal and advocate of colonial selfgovernment, saw Toy's challenge as one undermining responsible government and the authority of the executive (Bennett 2007: 191-201). Chief Justice Higinbotham asserted the autonomy of a colonial government, even against imperial norms:

The Executive Government of Victoria has the right and the duty, subject to the approval of Parliament, and so far as may be consistent with treaty obligations of the Crown, to do all acts, including the exclusion of aliens from Victoria, necessary for the administration of public affairs and for the security of the people of Victoria (Toy v Musgrove 1888 VLR 349).

The Chief Justice, however, was unable to persuade four of his colleagues of this view. The court majority insisted that 'the prerogative to exclude aliens' was not possessed by the colonial government in Victoria. A narrower view of the case, focussed on interpretation of the statutory provisions alone, was taken by another dissenting judge, and former premier of Victoria, Justice Kerferd. Finding comfort in that approach, the Victorian government subsequently appealed the Full Court's decision to the Privy Council in London. In 1891, the Privy Council overturned the Victorian Supreme Court judgment (Musgrove v Toy 1891 AC 272). Moreover it determined that an alien did not have the right to contest in a British court, a decision taken to exclude him. Chung Teong Toy had nevertheless in November 1888 succeeded in his claim for damages, being awarded 150 pounds (Argus 2 Nov 1888: 6-7). The outcome was a significant victory for the Melbourne Chinese community which had supported him and others affected by the government's policy (Welch 2003). The significance of their actions was amplified by contemporaneous events in Sydney.

After being refused landing of his passengers at Melbourne, Captain Roy had taken the Afghan to Sydney. There he faced even more determined opposition with massed crowds opposing the landing of any Chinese, and the NSW Premier, Sir Henry Parkes, 'drunk with 
the noise of agitation' as Melbourne's Argus reported (Argus 18 May 1888: 6). Once again, the Chinese passengers were denied the right of landing, in spite of the status of some of them as residents and even naturalised subjects of the colony. After a week on board ship in Sydney harbour, three passengers obtained a writ of habeas corpus on 14 May 1888 before the Chief Justice in chambers. In subsequent proceedings, the NSW Supreme Court proved no more a friend to the government than its Victorian counterpart. The outcome for the three men was however varied; two were discharged from custody while the third failed in his application. The court's decisions were shaped by the objective facts attached to the prior status in the colony of the three appellants. Lo Pak was a long-time resident and had a certificate exempting him from the provisions of the 1881 Influx of Chinese Restriction Act: his release was ordered by the court on 17 May 1888 (Ex parte Lo Pak, 1888 NSWLR 221). Leong Kum, a passenger who had paid the poll tax of 10 pounds to the ship's captain, was also granted his freedom to land, on May 231888 (Ex parte Leong Kum, 1888 NSWLR 250). Lau You Fat, however, had no exemption certificate, nor had he paid the poll tax. Instead he presented papers of naturalisation that had been granted in Victoria. The same court that had released Lo Pak and Leong Kum declined to look with favour on Lau You Fat, declaring that naturalisation papers did not have extra-territorial validity, although one of the three judges was of a mind to agree that they did (Ex parte Lau You Fat 1888 NSWLR 269).

The decisions of the NSW Supreme Court were a determined assertion of judicial authority. The judges did not shrink from vigorous criticism of a government that had been shown to have acted illegally in prohibiting the landing of passengers who had met the legal requirements of the migration statutes. Encouraged by these outcomes, more Chinese passengers used the same legal tactic in early June 1888 to enforce their release from the $S S$ Changsha - on this occasion the Chief Justice berated the government for its wilful 
indifference to the court's early judgments. The government was forced to give way (Ex parte Woo Tin 1888 NSWLR 493; SMH, 6 Jun 1888: 5).

The legal victory proved short-lived. By July 1888 the NSW government had enacted an amended restriction statute that abolished the availability of naturalisation for Chinese residents and imposed prohibitive entry requirements for incoming passengers. The legal contests in 1888 had asserted Chinese entitlements to be heard in colonial courts and be treated equitably - the longer term impact nevertheless was to stimulate the colonial governments to guard ever more jealously the British character of Australasian settlement (Markus 1994; Norris 1975; Willard 1967). Even so, colonial courts continued to watch closely the administration of these laws. Hence in 1901, a Western Australian man, Choong Man Kit, successfully appealed a conviction of being a prohibited immigrant under the State's 1897 Immigration Restriction Act. His appeal may have been inspired by an earlier successful defence against such a charge mounted by two Chinese men at a rural police court in 1899 (Ryan 1995a: 69) (West Australian 29 December 1899: 5). Quashing Choong's conviction in 1901, two judges of the Supreme Court rebutted the lower court magistrate's presumption that the burden of proving he was not a prohibited immigrant fell on Choong. Furthermore, the court determined that the 1897 Act did not refer to Chinese at all, 'for whose immigration into Western Australia provision had already been made by law'. For Justice Hensman 'it was hardly necessary to say that if a Chinaman was not prohibited by statute, he was just as much entitled to the full benefit of the law of England as an Australian, and it was one of their principles that a man had to be proved guilty of a charge before he could be imprisoned' (Man Kit v Sampson 1901 WALR 71; Western Mail 25 May 1901: 14). 


\section{Law as Politics}

In the stories recounted here we can see two larger histories at work. One is about the law's authority in colonial states, in this case Australian colonies of the later nineteenth and early twentieth centuries. The other is about Chinese settler identity and agency in this same period. Both histories share much with those told across the Pacific, on the west coast of North America, during these same decades.

Taking action to assert one's rights through appealing convictions or adverse outcomes in lower courts was conditional on knowledge of the avenues available to aggrieved parties and a capacity to afford the costs of such appeals. Behind the readiness of the Chinese immigrants to seek legal remedies, there was a legal culture in late Qing China that encouraged such practices, even if the institutional context was profoundly different (Huang 2001; Macauley 1998). Crucial to the activism of Chinese litigants in the colonies were the strong associations maintained by Chinese immigrants in their different diasporic destinations (Fitzgerald 2007; Ngai 2011; Yong 1977). Such support from native or district associations has been shown to lie behind the extraordinary legal campaigns using habeas corpus actions that contested the restrictive immigration legislation of California from the 1880 s to the 1900s, before the US Congress brought a halt to such possibilities (Chan 1991; Salyer 1995). In Melbourne in 1888, the Chinese Residents Association similarly pushed for legal action to contest the Victorian government's exclusions of the Chinese passengers on the Afghan and other vessels. Collective defence was also evident in other kinds of legal cases, especially those appealing convictions in gambling cases and perhaps in opium prosecutions as well. The official law reports rarely disclosed this extra-curial context of the cases before the judges but such collective support from community leaders and associations was surely critical to the continuing capacity of the Chinese to turn to law in the Australian colonies. 
The other history marked out by the cases we have reviewed here was in turn an encouragement to the litigation. A protracted experience of adverse court outcomes would hardly have conduced to future litigation. But both at lower court and at Supreme Court level we see evidence of the relative fairness of legal decision-making. In their reasoning we see judges exercising their training in common law. The close attention to the provisions of statute (evident as much in Western Australia in 1901 as in the Victorian and NSW courts in 1888) as well as the forms of common law also signalled the legalism that structured judicial practice, an enduring feature of the Australian judiciary (Genovese 2013).

The practices of gross discrimination of a magistrate at Castlemaine on Victoria's goldfields thus stood out in contrast to other patterns of Chinese success in litigation. When we move onto the large stage of the late nineteenth century immigration cases, at the very heart of colonial political agitation around the Chinese presence in Australia, we witness an extraordinary story. Not only was there a significant success of Chinese litigants in NSW, Victoria and Western Australia. What was equally notable was the combative position of judges who rejected the idea that colonial governments could do what they liked to stop Chinese immigrants, and that lower courts were free to make up their own rules about the rights of Chinese defendants before them. Instead the courts insisted, as they did for some years in British Columbia in the 1880s, on applying legal standards that respected the (almost) equal standing even of aliens in British courts (McLaren 1991). Habeas corpus, a prerogative writ with a very long if uneven history in the common law (Halliday 2010), proved to be a powerful weapon in the hands of Chinese litigants. And in turn, such litigation provoked heated constitutional debate that had a larger effect in shaping pre-federation political attitudes and decisions in the colonies.

Observing these two histories we might conclude with this thought. The history of the White Australia Policy was once written as a history only of exclusion, with its 'dichotomous 
descriptions of racial differences and of victims and oppressors in the federation narrative' (Jones 2004: 220). The histories of law and litigation that we have noticed here suggest another kind of history - one in which immigration law in Australia can be seen as a response to the success of Chinese seeking legal remedies to enforce government conformity with its own laws, gaining judicial support in so doing, and in turn provoking ever more radical political restraints on people movement that were expressed in the emerging legal regimes regulating immigration (Bashford \& Gilchrist 2012). Against the background of litigation outlined here, it is not surprising that the very administration of the White Australia policy would in turn be shaped by the challenges thrown up by later Chinese litigants, making their way into and out of the country that sought to exclude them, but which some also called home. 
Appendix: Appeal court cases involving Chinese litigants, Australian jurisdictions 1864 -1912

\begin{tabular}{|c|c|c|c|}
\hline Case & Jurisdiction & Year & Notes \\
\hline Ex Parte Ah Tchin and others & NSW & 1864 & Gold Fields Act \\
\hline $\begin{array}{l}\text { Ex parte Yee v Medical } \\
\text { Board of Victoria }\end{array}$ & VIC & 1875 & Medical registration \\
\hline $\begin{array}{l}\text { Cooey Hing and others v } \\
\text { Sadleir }\end{array}$ & VIC & 1875 & Lotteries case \\
\hline $\begin{array}{l}\text { Ex parte Yee Quock Ping V } \\
\text { Medical Board of Victoria }\end{array}$ & VIC & 1875 & Medical registration \\
\hline $\mathrm{R} v \mathrm{Ah}$ On & NSW & 1875 & Criminal law \\
\hline Ah Fan v Sturt & VIC & 1876 & Lotteries case \\
\hline Ho A Mie v Ho A Mie & VIC & 1880 & Divorce case \\
\hline R v Li Chi & NSW & 1881 & Lotteries case \\
\hline $\begin{array}{l}\text { Chun Goon v The Reform } \\
\text { Gold Mining Company }\end{array}$ & VIC & 1882 & Contract \\
\hline $\begin{array}{l}\text { In the matter of the estate of } \\
\text { Mary Ann Khoon Soon }\end{array}$ & VIC & 1882 & Estate \\
\hline $\begin{array}{l}\text { Barclay and others v Why Te } \\
\text { Hong }\end{array}$ & NSW & 1882 & Trespassing \\
\hline Ah Kang v The ASN & VIC & 1883 & Contract \\
\hline Shillinglaw v Ah Hen & VIC & 1885 & Opium case \\
\hline R v Ah Jong & NSW & 1885 & Opium case \\
\hline Shack Yin v Ah Fook & NSW & 1885 & Bankruptcy \\
\hline R v Ah Chack & VIC & 1886 & Lotteries case \\
\hline Ah Sue v Call & VIC & 1886 & Lotteries case \\
\hline R v Ah Tow & NSW & 1886 & Lotteries case \\
\hline Ah Chin v Thiel & VIC & 1887 & Civil suit \\
\hline Ah Hing & NSW & 1887 & Gaming case \\
\hline Toy v Musgrove & VIC PC & 1888 & Immigration \\
\hline Ex parte Lau You Fat & NSW & 1888 & Immigration \\
\hline Ex parte Leong Kum & NSW & 1888 & Immigration \\
\hline Ex parte Lo Pak & NSW & 1888 & Immigration \\
\hline Yen Yu v Worthington & VIC & 1888 & Liquor license \\
\hline Lew Kim & VIC & 1891 & Civil law \\
\hline R v Lum Hook & QLD & 1891 & Perjury \\
\hline Nixom v Ah Fook & VIC & 1892 & Lotteries \\
\hline R v Ah Sam & QLD & 1895 & Criminal case \\
\hline Yit Tie Chee v Mee Shuey & VIC & 1895 & Contract \\
\hline $\begin{array}{l}\text { Lee Gow v Williams, ex } \\
\text { parte Williams }\end{array}$ & QLD & 1895 & Property \\
\hline $\begin{array}{l}\text { Gleeson v Ah Houn Gleeson } \\
\text { v Ah Yen }\end{array}$ & VIC & 1896 & Lotteries case \\
\hline $\begin{array}{l}\text { Jong Song v Joy Hoy and } \\
\text { others }\end{array}$ & QLD & 1897 & Criminal law \\
\hline Re Ah Chung and others & NSW & 1898 & Customs Act \\
\hline R v See Shing & WA & 1900 & Immigration \\
\hline Chong Man Kit v Henry & WA & 1901 & Immigration \\
\hline
\end{tabular}




\begin{tabular}{|l|l|r|l|}
\hline Sampson & & & \\
\hline Kavanagh v Ah Hing & WA & 1901 & Criminal law \\
\hline Hop Lee v J M Mill & WA & 1902 & Civil law \\
\hline Gibson v Lee Suey & VIC & 1903 & Gold Act case \\
\hline Christie v Ah Foo & VIC & 1904 & Immigration \\
\hline Ah Yick v Lehmert & HCA & 1905 & Immigration \\
\hline Chia Gee v Martin & HCA & 1905 & Immigration \\
\hline $\begin{array}{l}\text { R v Lindbergh, ex parte Jong } \\
\text { Hing }\end{array}$ & HCA & 1905 & Immigration \\
\hline Quan Yick v Hinds & HCA & 1905 & Criminal law \\
\hline In re Ah Lin & QLD & 1905 & Estate \\
\hline Freedman Co v Dan Chi Lin & WA & 1905 & Civil law \\
\hline $\begin{array}{l}\text { Quan Sing Co v E J Hayes } \\
\text { Co }\end{array}$ & WA & 1905 & Civil law \\
\hline Lee Shew v Frank Vincent & WA & 1905 & Factories Act \\
\hline Ah Sheung v Lindberg & VIC HCA & 1906 & Immigration \\
\hline Ah Chi v War Lee & WA & 1906 & Civil law \\
\hline Angus Gray v Ah Min & WA & 1906 & Civil law \\
\hline $\begin{array}{l}\text { Ah Ying and Ah Chung v } \\
\text { Frank Vincent }\end{array}$ & WA & 1906 & Factories Act \\
\hline Montague v Ah Shen & VIC & 1907 & Gaming \\
\hline Ah Yin v Christie & HCA & 1907 & Immigration \\
\hline Cheong v Lohmann & VIC & 1907 & Contract \\
\hline Lee Fan v Dempsey & WA HCA & 1907 & Gaming \\
\hline Lawson v Chin Jin & WA & 1907 & Civil law \\
\hline Potter v Minahan & VIC HCA & 1908 & Immigration \\
\hline Moroney v Quock Yen & QLD & 1908 & Opium case \\
\hline $\begin{array}{l}\text { Adelaide Steamship Co v } \\
\text { Quan Sing }\end{array}$ & WA & 1908 & Civil law \\
\hline R v Ah Lin & HCA & 1909 & Opium case \\
\hline Baxter v Ah Way & HCA & 1909 & Opium case \\
\hline Lee Fay v Vincent & WA HCA & 1909 & Factories Act \\
\hline Seymour v On Yet & QLD & 1910 & Opium \\
\hline R v Sing & HCA & 1911 & Immigration \\
\hline Fon Hock & TAS & 1911 & Estate \\
\hline Quon Tat & TAS== & 1912 & Immigration \\
\hline
\end{tabular}

Note: 'Jurisdiction' denotes the jurisdiction of the court which heard the case; HCA is the High Court of Australia (established in 1901), which heard some cases on appeal direct from police courts, others from decisions already given in State (formerly colonial) Supreme Courts; PC is Privy Council. 


\section{References}

Bashford, Alison and Gilchrist, Catherine. 2012. "The Colonial History of the 1905 Aliens Act." The Journal of Imperial and Commonwealth History, 40(3), 409-437.

Bennett, John Michael. 2003. Sir John Pedder: First Chief Justice of Tasmania, 1824-1854. Lives of the Australian Chief Justices. Annandale, N.S.W, Federation Press.

2006. Colonial Law Lords: (The Judiciary and the Beginning of Responsible Government in New South Wales). Sydney, Federation Press.

2007. George Higinbotham: Third Chief Justice of Victoria 1886-1892. Lives of the Australian Chief Justices. Annandale, N.S.W, Federation Press.

Bolton, Geoffrey Curgenven and Byrne, Geraldine. 2005. May it Please Your Honour: A History of the Supreme Court of Western Australia 1861-2005. Perth, Supreme Court of Western Australia.

Cai, Shaoqin. 2004. "From Mutual Aid to Public Interest: Chinese Secret Societies in Australia." In After the Rush: Regulation, Participation and Chinese Communities in Australia, 1860-1940. Sophie Couchman, Paul Macgregor, and John Fitzgerald, eds. Kingsbury, Vic., Otherland Literary Journal, pp. 133-152.

Castles, Alex Cuthbert. 1982. An Australian Legal History. Sydney, Law Book Co.

Chan, Sucheng ed. 1991. Entry Denied: Exclusion and the Chinese Community in America, 1882-1943. Asian American History and Culture, Philadelphia, Temple University Press.

Cronin, Kathryn. 1982. Colonial Casualties: Chinese in early Victoria. Melbourne, Melbourne University Press.

Curthoys, Ann. 2003. "Liberalism and Exclusionism: A Prehistory of the White Australia Policy." In Legacies of White Australia: Race, Culture and Nation. Laksiri Jayasuriya, David Walker and Jan Gothard eds. Crawley, UWA Press, pp. 8-32, 216-220, 251-256.

2001, "Men of All Nations, Except Chinamen: Europeans and Chinese on the Goldfields of New South Wales." In Gold: Forgotten Histories and Lost Objects of Australia.: Iain McCalman, Alexander Cook, and Andrew Reeveseds, Cambridge, Cambridge University Press.

Finnane, Mark and Richards, Jonathan. 2010. "Aboriginal Violence and State Response: Histories, Policies, Legacies in Queensland 1860-1940." ANZ Journal of Criminology, 43(2), 238-262.

Fitzgerald, John. 2007. Big White Lie: Chinese Australians in White Australia. Sydney, University of New South Wales Press.

Genovese, Ann. 2013. "Australian Communist Party of Australia v The Commonwealth: Histories of Australian Legalism.” Australian Historical Studies, 44(1), 6-22. 
Halliday, Paul D. 2010. Habeas Corpus: From England to Empire. Belknap Press of Harvard University Press.

Holst, Heather. 2004. "Equal Before the Law?: The Chinese in the Nineteenth-century Castlemaine Police Courts." Journal of Australian Colonial History, 6, 113-36.

Huang, Philip. C.C. 2001. Code, Custom, and Legal Practice in China: The Qing and the Republic Compared (Law, Society, and Culture in China). Stanford, Calif, Stanford University Press.

Jones, Paul. 1998. Alien Acts: The White Australia Policy, 1901 to 1939. Ph. D thesis, University of Melbourne.

"What Happened to Australia's Chinese between the World Wars?" In After the Rush: Regulation, Participation and Chinese Communities in Australia, 1860-1940, Sophie Couchman, Paul Macgregor and John Fitzgerald eds. Kingsbury, Vic., Otherland Literary Journal, pp. 217-236.

Kercher, Bruce. 1995. An Unruly Child: A History of Law in Australia. St Leonards, Allen \& Unwin.

Khoo, Tseen and Noonan, Rodney. 2011. "Wartime Fundraising by Chinese Australian Communities." Australian Historical Studies, 42(1), 92-110.

Lake, Marilyn and Reynolds, Henry. 2008. Drawing the Global Colour Line: White Men's Countries and the International Challenge of Racial Equality. Carlton, Vic, Melbourne University Publishing.

Macauley, Melissa Ann. 1998. Social Power and Legal Culture: Litigation Masters in Late Imperial China (Law, Society, and Culture in China). Stanford, Calif, Stanford University Press.

Macgregor, Paul ed. 1995. Histories of the Chinese in Australasia and the South Pacific: Proceedings of an International Public Conference Held at the Museum of Chinese Australian History, Melbourne, 8-10 October 1993. Melbourne, The Museum of Chinese Australian History.

Markus, Andrew. 1994. Australian Race Relations 1788-1993 (Australian Experience). St Leonards, NSW, Allen \& Unwin.

Markus, Andrew. 1979. Fear and Hatred: Purifying Australia and California, 1850-1901. Sydney, Hale \& Iremonger.

May, Cathy. 1984. Topsawyers, the Chinese in Cairns, 1870-1920. Townsville, James Cook University. History Department.

McClain, Charles J. and McClain Laurence Wu .1991. "The Chinese Contribution to the Development of American Law. In Entry Denied: Exclusion and the Chinese Community in America, 1882-1943. Chan Sucheng ed. Asian American History and Culture, Philadelphia, Temple University Press. 
McCoy, Alfred W. 1980. Drug Traffic: Narcotics and Organized Crime in Australia. Sydney, Harper \& Row.

McKeown, Adam. 2008. Melancholy Order: Asian Migration and the Globalization of Borders. Columbia University Press.

McLaren, John. 1991. "The Early British Columbia Supreme Court and the "Chinese Question': Echoes of the Rule of Law.” Manitoba Law Journal, 20, 107-147.

2011. Dewigged, Bothered, and Bewildered: British Colonial Judges on Trial, 18001900. University of Toronto Press.

McPherson, Bruce Harvey. 1989. The Supreme Court of Queensland, 1859-1960: History Jurisdiction Procedure. Sydney, Butterworths.

Ngai, Mae. M. 2011. "Chinese Miners, Headmen, and Protectors on the Victorian Goldfields, 1853-1863.” Australian Historical Studies, 42(1), 10-24.

Norris, Ronald. 1975. The Emergent Commonwealth: Australian Federation, Expectations and Fulfilment 1889-1910. Carlton, Vic, Melbourne University Press.

New South Wales Parliament. 1891. Report of the Royal Commission on Alleged Chinese Gambling and Immorality and Charges of Bribery Against Members of the Police Force, Appointed August 20, 1891. Available from: http://archive.org/details/cu31924023440187 (accessed 25 June 2012).

O'Hara, John. 1988. A Mug's Game: A History of Gaming and Betting in Australia. Kensington, New South Wales University Press.

Ryan, Jan. 1995a. Ancestors: Chinese in Colonial Australia. Fremantle, Fremantle Arts Centre.

Ryan, Jan. 1995b. "It's a crime! Chinese Immigrants and the Law in Wesetrn Australia." In Histories of the Chinese in Australasia and the South Pacific: Proceedings of an International Public Conference held at the Museum of Chinese Australian History, Melbourne, 8-10 October 1993. Paul Macgregor ed. Melbourne, The Museum of Chinese Australian History, pp. 341-353.

Salyer, Lucy. E. 1995. Laws Harsh As Tigers: Chinese Immigrants and the Shaping of Modern Immigration Law. The University of North Carolina Press.

Strange, Carolyned. 1996. Qualities of Mercy: Justice, Punishment, and Discretion. Vancouver, B.C., UBC Press.

Welch, Ian. 2003. Alien Son: The Life and Times of Cheok Hong Cheong (Zhang Zhuoxiong) 1851-1928. Ph. D thesis. ANU.

Willard, Myra. 1967. History of the White Australian Policy to 1920. Carlton South, Vic, Melbourne University Press. 
Woods, Gregory D. 2002. A History of Criminal Law in New South Wales: The Colonial Period, 1788-1900. Annandale NSW, Federation Press.

Yarwood, Alexander T. 1964. Asian Migration to Australia: The Background to Exclusion, 1896-1923. Carlton, Vic, Melbourne University Press.

Yong, Ching Fatt. 1977. The New Gold Mountain: The Chinese in Australia, 1901-1921. Richmond, S. Aust, Raphael Arts. 